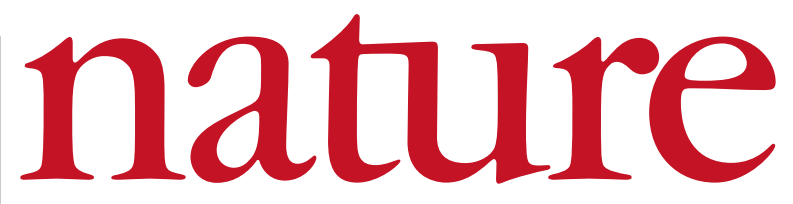

20 May 2004 Volume 429 Issue no 6989

\title{
Future shock
}

At first glance, India's electorate has just put the brakes on the country's modernization, by ousting a government that has promoted entrepreneurship and invested in high technology. But appearances can be deceptive.

$\mathrm{F}$ ew observers anticipated last week's impressive Indian election victory by the Congress Party, led by Italian-born Sonia Gandhi, widow of slain prime minister Rajiv Gandhi.

The defeated government of the nationalist Bharatiya Janata Party (BJP) was credited with nurturing rapid economic growth in India and attracting foreign investment. During its rule, according to some estimates, 250,000 expatriates returned home, many of them scientists and engineers drawn into the booming biotechnology and information-technology sectors. In the past couple of years, the economy has expanded at an unprecedented annual rate of around $8 \%$.

The BJP government increased the amount that India spends on research and development from $0.6 \%$ of gross domestic product in 1999 to $1.1 \%$ today - and it claimed that this would rise to $2 \%$ by 2007. It also supported ambitious industrial ventures, including the beginnings of a civilian aircraft industry, the arrival of telemedicine in remote villages, and the expansion of higher education.

But many of the reforms that laid the groundwork for these successes were initiated by the Congress Party before it lost power in 1998. Despite the panic in the financial markets as Gandhi negotiated with the left-wing parties whose support will be needed to form a stable government, there is little reason to fear that the economic expansion will end with the rule of the BJP.

Support for scientific research is likely to be largely maintained by the incoming government. The Congress Party's traditional rationalism will also be welcomed by many scientists, who may be glad to see the back of former BJP science minister Murli Manohar Joshi, who sought to persuade universities to teach astrology (see Nature 411, 227;2001). Joshi was defeated at the polls in Uttar Pradesh.

Nevertheless, the new government must address a series of important science-related challenges. The BJP embraced technology as the solution to many national problems. Its manifesto promised to usher in a second 'green revolution' with the help of biotechnology, and to engage in substantial civil-engineering projects that would link up rivers to improve water supplies (see Nature 422, 790; 2003).

Both approaches were criticized by environmentalists, who will hold more sway with the new government. A more cautious approach can therefore be expected in pursuing agricultural biotechnology in particular. Gandhi must ensure that this caution doesn't leave India's farmers grappling with outdated seeds, tools and methods.

One of India's next major appointments on the international stage will arise next spring, when the nuclear non-proliferation treaty is due for renewal. The Congress Party has said that it will maintain the nuclear weapons that the BJP tested in 1998, but can be expected to revive India's role in pressing states with nuclear weapons to fulfil their commitments under the treaty.

India also holds a pivotal position on the World Trade Organization's Trade-Related Aspects of Intellectual Property Rights (TRIPS) agreement, which is supposed to harmonize patent rules. India is due to comply with TRIPS by January next year. But it will be interesting to see how the necessary legislation fares in the new parliament, given that Congress's supporters will be hurt by reforms that could undermine India's generic-drugs industry and increase the cost of healthcare.

This conflict between market-friendly reform and the grim reality of life in India's villages and cities partly explains last week's electoral shock. It is a good thing that the conflict is being resolved through the ballot box and not the barrel of a gun. Investors are not always rational — but if they are, the message they will take home from last week's smooth transfer of power is that India's young institutions are well equipped to underpin the country's development.

\section{Equal treatment under the law}

\section{If this fundamental right is denied to visiting researchers, the quality of US science will suffer.}

S ince February 2003, Iranian physicist Shahram Rahatlou has been barred from entering the government lab where he worked. The security officials who came to his door never told him what he had done wrong. They said there would be no appeal.

The lab is not in Iran, but at the Stanford Linear Accelerator Center (SLAC) in California. Rahatlou had been working there for nearly five years when officers from the US Department of Energy (DOE) visited him. He had, by all accounts, been an exceptional physicist. SLAC is a purely academic laboratory, which houses no classified research, and the experiment on which he was working makes all its findings publicly available. Even the lab's scientific leaders don't know why Rahatlou was barred from the premises (see page 229).

The DOE, which manages nuclear weapons facilities in addition to running civilian laboratories such as SLAC, has a duty to protect national security. Since the attacks of 11 September 2001, it has subjected many foreign researchers to background checks. But in a democracy, those who come under suspicion should have the right to know the accusations that they face, and have the right to appeal.

Rahatlou may come from a state designated as a "sponsor of terror", but he is also one of the most hard-working physicists in a collaboration of more than 600 researchers from 10 countries. It is time for the US government to take a second look at his case. The DOE says the matter cannot be discussed further because it is classified, but many scientific officials — including John Marburger, the president's science adviser - have high-level security clearance. It is up to them to find a way to give Rahatlou his day in court.

The shocking pictures that have emerged from the Abu Ghraib jail in Iraq have sullied the United States' reputation across the Islamic world. Rahatlou's case is not in the same league of infamy. But it adds to a damaging impression that US officials are prepared to ride roughshod over those they see as potential enemies in the 'war on terror'. If US labs are to continue to attract the world's best scientific talent, visitors need to know that they will be treated with respect and dignity under the law. 